\title{
Assessing the Productivity, Quality and Profitability of Orange Fleshed Sweet Potatoes Grown in Riverbank of the Tista Floodplain Agro-Ecological Zone of Bangladesh
}

\author{
Abdullah-Al Mahmud ${ }^{1}$, Md Jahangir Alam ${ }^{1} \mathbb{D}$, Simon Heck ${ }^{2} \mathbb{D}$, Wolfgang J. Grüneberg ${ }^{3}$, Debashish Chanda ${ }^{4}$, \\ E. H. M. Shofiur Rahaman ${ }^{4}$, Md Samim Hossain Molla ${ }^{5}$, Md Mazharul Anwar ${ }^{6}$, Md Al-Amin Hossain Talukder ${ }^{5}$,

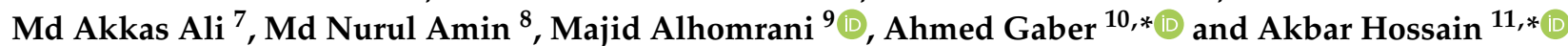

1 On-Farm-Research Division, Bangladesh Agricultural Research Institute, Gaibandha 5700, Bangladesh; mahmud.tcrc@gmail.com (A.-A.M.); jahangir.bari@gmail.com (M.J.A.)

2 International Potato Center (CIP), Africa Regional Office, ILRI Campus, P.O. Box 25171-00603,

Nairobi 00100, Kenya; s.heck@cgiar.org

3 International Potato Center (CIP), Avenida La Molina 1895, Distrito de La Molina Lima 12, Lima 15023, Peru; w.gruneberg@cgiar.org

4 International Potato Center (CIP), Dhaka 1213, Bangladesh; d.chanda@cgiar.org (D.C.); E.RAHAMAN@CGIAR.ORG (E.H.M.S.R.)

check for updates

Citation: Mahmud, A.-A.; Alam, M.J.; Heck, S.; Grüneberg, W.J.; Chanda, D.; Rahaman, E.H.M.S.; Molla, M.S.H.; Anwar, M.M.; Talukder, M.A.-A.H.; Ali, M.A.; et al. Assessing the Productivity, Quality and Profitability of Orange Fleshed Sweet Potatoes Grown in Riverbank of the Tista Floodplain Agro-Ecological Zone of Bangladesh. Agronomy 2021, 11, 2046. https:// doi.org/10.3390/agronomy11102046

Academic Editors: Umberto Anastasi and Aurelio Scavo

Received: 5 September 2021

Accepted: 8 October 2021

Published: 12 October 2021

Publisher's Note: MDPI stays neutral with regard to jurisdictional claims in published maps and institutional affiliations.

Copyright: (c) 2021 by the authors Licensee MDPI, Basel, Switzerland. This article is an open access article distributed under the terms and conditions of the Creative Commons Attribution (CC BY) license (https:// creativecommons.org/licenses/by/ $4.0 /)$
5 On-Farm-Research Division, Bangladesh Agricultural Research Institute, Rangpur 5402, Bangladesh; samimmolla@yahoo.com (M.S.H.M.); alamintalukder@yahoo.com (M.A.-A.H.T.)

6 On-Farm-Research Division, Bangladesh Agricultural Research Institute, Rajshahi 6201, Bangladesh; anwar.sci.bari@gmail.com

7 On-Farm-Research Division, Bangladesh Agricultural Research Institute, Gazipur 1701, Bangladesh; akkasbari@gmail.com

8 Breeder Seed Production Center, Bangladesh Agricultural Research Institute, Panchagrah 5020, Bangladesh; nuru101141@yahoo.com

9 Department of Clinical Laboratories Sciences, The Faculty of Applied Medical Sciences, Taif University, P.O. Box 11099, Taif 21944, Saudi Arabia; m.alhomrani@tu.edu.sa

10 Department of Biology, College of Science, Taif University, P.O. Box 11099, Taif 21944, Saudi Arabia

11 Department of Agronomy, Bangladesh Wheat and Maize Research Institute, Dinajpur 5200, Bangladesh

* Correspondence: a.gaber@tu.edu.sa (A.G.); akbarhossainwrc@gmail.com (A.H.)

Abstract: Orange fleshed sweet potatoes (OFSP) are desirable for high productivity and profitability and their distribution to improve the nutrition of river bank inhabitants of Gaibandha and Rangpur districts of Bangladesh. In this context, a field trial was conducted in two riverbank-based farmers' fields such as Saghata, Gaibandha, and Pirganj, Rangpur, particularly in the Active Tista Floodplain Agro-ecological Zone of Bangladesh. Four OFSP varieties were evaluated, i.e., G1: BARI SP-8; G2: BARI SP-12; G3: BARI SP-14; G4: BARI SP-15, along with one local cultivar as a control (Red skin with white flesh). Significant variations among the sweet potato genotypes were noted for a number of tuberous roots plant ${ }^{-1}$, length of root diameter of roots, tuberous root weight plant ${ }^{-1}$, root yield (fresh), root yield (dry), beta-carotene yield, as well as energy output. Over the locations, BARI SP-12 produced about $73 \%$ higher root yield $\left(32.00 \mathrm{t} \mathrm{ha}^{-1}\right)$ and it was like the BARI SP-8 $\left(31.07 \mathrm{t} \mathrm{ha}^{-1}\right)$, which produced about $68 \%$ higher yield in comparison with local cultivar $\left(18.51 \mathrm{t} \mathrm{ha}^{-1}\right)$. Across the location, BARI SP-8 performed better in root yield $\left(31.89 \mathrm{t} \mathrm{ha}^{-1}\right)$ in Gaibandha, $69 \%$ superior to local cultivar, whereas BARI SP-12 performed better in Rangpur ( $33.66 \mathrm{t} \mathrm{ha}^{-1}$ ), which was $86 \%$ greater than the local sweet potato cultivar. Considering the root dry yield production, BARI SP-8 produced the highest in the Gaibandha location after that Rangpur location. Further, BARI SP-14 had wider adaptability and stability over the year and location depended on the AMMI model. The beta carotene yield (Vitamin-A precursor) ranged 336-2957 $\mathrm{kg} \mathrm{ha}^{-1}$ among the OFSP varieties, whereas the highest $\left(2957 \mathrm{~kg} \mathrm{ha}^{-1}\right)$ carotene was recorded in BARI SP-14, similar to BARI SP-15 $\left(2952 \mathrm{~kg} \mathrm{ha}^{-1}\right)$ but was much lower in BARI SP-8 and BARI SP-12. Moreover, BARI SP-8 and BARI SP-12 were also economically profitable in terms of gross margin (3233 and 3364 US $\$ \mathrm{ha}^{-1}$, respectively), net return (3039 and 3170 US\$ ha ${ }^{-1}$, respectively) and BCR (3.21 and 3.31, respectively, vs. 1.91) due to higher returns with a similar production cost of the local cultivar. The results suggested that BARI SP-8 
is economically profitable in the riverbank areas of Gaibandha, and BARI SP-12 is suitable for the riverbank areas of Rangpur.

Keywords: sweet potato; beta-carotene; yield; profitability

\section{Introduction}

Sweet potato, a perennial root crop belonging to the family of Convolvulaceae, has several flesh colors (white, yellow, cream, purple and orange) [1,2]. Among them, the orange, white and cream flesh sweet potatoes are commonly cultivated and consumed. It is the seventh most important crop in the world [3,4]. It is grown globally in more than a hundred countries with an average yield of $12.20 \mathrm{t} \mathrm{ha}^{-1}$ from 8.62 million ha of land [5]. The most commonly edible parts of the sweet potatoes are the tuberous roots, while the leaves are also important [1,2] and an important staple food across the Asian, African and Pacific region countries of the world. Sweet potato is also being used as cattle feed $[1,6,7]$. Sweet potato is considered as a healthy food having a low level of fat and protein, but rich in carbohydrates.

Orange-fleshed sweet potatoes (OFSP) are being considered as resilient crops due to its high carotenoid content (Precursor of Vitamin-A) and good yields, and also rich carbohydrates, vitamins and minerals [3,4] which can improve the nutrition of underprivileged farmers in numerous developing nations. Orange-fleshed sweet potatoes are also high-yielding with the capacity to generate more edible energy than wheat, rice or cassava per unit area [3]. Its root flesh and green leaves are great sources of antioxidants [8], minerals ( $\mathrm{Zn}, \mathrm{K}, \mathrm{Na}, \mathrm{Mn}, \mathrm{Ca}, \mathrm{Mg}$ and Fe), fiber and vitamin C [9].

Sweet potato, one of the preferred root crops due to the highest dry matter content for human consumption, out of which $70 \%$ of it is composed of starch $[1,10]$. A good sweet potato variety possesses a great amount of dry matter which is treated as an essential characteristic [11]. It can also be considered as one of the best meals assessed for long-time space travel, due to the fact of their nutritional attributes [12].

OFSP's are also quite excellent sources of vitamin-A $[8,13]$ and its main pigments, especially $\beta$-carotene and carotenoids, which are closely associated with the improvement of the immune system of human beings, and reduces the risk of cardiovascular complexities, age-related macular degeneration, and cataract development [14]. So, betacarotene enriched sweet potatoes could be used successfully in small-scale interventions in the riverbanks and rural areas to improve nutrition status and to combat vitamin- $\mathrm{A}$ deficiency-induced diseases.

In Bangladesh, the cultivation of sweet potatoes is concentrated in the riverbanks and riverine islands (called the Char area; formed from sedimentation). Around 6.5 million (around $4 \%$ ) of the Bangladeshi people live in the riverine islands (Char areas) and most of them are marginalized. Poverty is the common to the riverine island people; some of them are vulnerable and they usually cultivate sweet potato local cultivars in their fallow lands where other crops are not cultivated. Cultivating OFSP in the riverine islands of northern Bangladesh have a reasonable benefit. The soils in the northern riverine islands/Char areas are sandy and sandy loam type where water scarcity is common for rice cultivation and also challenging to cultivate other cereals such as wheat and maize. Sweet potatoes are cultivated on various soils, although good drained medium-textured and light (sandy to sandy loam) soils with a $\mathrm{pH}$ of $4.5-7.0[1,15]$ are preferred for better vegetative growth and root development. At present, sweet potato cultivation in Bangladesh is about 0.13 million hectares (Mha) with a production of 1.47 million tons (Mt) [5]. OFSP varieties are generally less drought tolerant than the white-fleshed (WF) cultivars [16] and the average yield of OFSP at farm level in the riverbanks and riverine islands is about $10-12 \mathrm{t} \mathrm{ha}^{-1}$ [5] where crops grown with less irrigation and minimum inputs compared to other crops grown; 
while the potential yield can be as high as $35-40 \mathrm{t} \mathrm{ha}^{-1}$ [17]. There is significant potential to increase the yield of sweet potato by bridging the yield gap in these communities.

Genotypes and environmental interactions are associated with the performance of the varieties that show stability when cultivating in different environments and is essential for achieving new and improved genotypes [18]. The Additive Main effect and Multiplicative Interaction (AMMI) biplot is used to explain test location and genotype performance in test environments [19]. The AMMI biplot analysis is an important Genotype Environment Interaction (GEI) assessment strategy that helps plant breeders/agriculturists to identify and select higher performing genotypes in specific environments [20,21]. AMMI Stability Value (ASV) illustrates the distance of origin from the point of adjustment between the IPCA2 (Interaction Principal Component Axes for the environment) value versus the IPCA1 (Interaction Principal Component Axes for genotype) value of the AMMI model [22]. This has led to the need for adaptation and stability testing to obtain high quality and adaptive genotypes in different locations. The new superior varieties selected in the multienvironment test are expected to be as stable and uniform as possible, although they are born in different environments. Sweet potato is one of the main crops of the river island which reflect a significant source of nutrition and an attractive, important role in the upkeep of food security and increasing the profits of sweet potato growers [23,24]. It is commonly cultivated in the country, especially concentrated in the northern riverbanks and give more profits with fewer investments [25].

Life in the riverbanks and riverine islands is both unpredictable and insecure as they are facing major hazards such as flash flooding, riverbank erosion and cost of land. Numerous Char inhabitants fight to make or buy sufficient food to consume, and malnutrition and micronutrient shortcomings are widespread in these areas. Identification of promising varieties for riverbanks and riverine islands from the existing International Potato Center (CIP) bred sweet potato varieties may provide farmers with higher yields and help ensure food security in Bangladesh. Therefore, the International Potato Center (CIP) and Bangladesh Agriculture Research Institute (BARI) are introducing OFSP as a resilient and healthy food crop that can provide both economic opportunities and nutritional benefits to these Char farmers.

At present, OFSP is studied for its versatility and adaptability in diversified climatic conditions. The present study considered the performance of CIP-bred sweet potato varieties in the northern parts of Bangladesh and the impact on the economy of sweet potato cultivation in the Char area with the following objectives: (i) to assess the field performance and stability of OFSP varieties at field level in riverbanks and riverine islands; (ii) to calculate the cost and income of sweet potato cultivation at the farm level.

\section{Materials and Methods}

\subsection{The Site, Season, Climatic Condition and Nutrient Status of the Experimental Field}

The trial was carried out in two locations, namely Pirganj $\left(25^{\circ} 23^{\prime} \mathrm{N}\right.$ and $\left.89^{\circ} 18^{\prime} \mathrm{E}\right)$ of Rangpur and Saghata $\left(25^{\circ} 10^{\prime} \mathrm{N}\right.$ and $\left.89^{\circ} 58^{\prime} \mathrm{E}\right)$ of Gaibandha districts, Bangladesh (representing AEZ 2: Active Tista Floodplain agro-ecological zone of Bangladesh), during November-March (winter time) of 2018-2019 and 2019-2020 crop season.

The experimental sites were in a sub-tropical climate zone and characterized by little rainfall (42-53 $\mathrm{mm}$ ) during the crop growing season (November-March) in the year. The monthly mean maximum temperature for the period of the sweet potato crop growth and development was mostly lower than the long-term averages in both locations, with some exception of 2018-2019 in Rangpur. On the other hand, the monthly mean minimum temperature was a little bit superior in Gaibandha than the long-term mean, but similar in Rangpur. The second crop year (2019-2020) was cooler in both the sites particularly in January, and the mean maximum temperature was about $1-3{ }^{\circ} \mathrm{C}$ lower than the 1 st year cropping season (Figure 1a,b). The monthly average maximum temperature was $26-34^{\circ} \mathrm{C}$ in Gaibandha and $22.8-30.2^{\circ} \mathrm{C}$ in Rangpur and the average monthly minimum temperature was $12-18{ }^{\circ} \mathrm{C}$ in Gaibandha and $11.1-17.3^{\circ} \mathrm{C}$ in Rangpur, respectively. January was the 
coolest month (average temperature vary between $11.1-12{ }^{\circ} \mathrm{C}$ ) and March was the warmest month (average temperature vary between $30.2-34^{\circ} \mathrm{C}$ ) in both locations (Figure 1 ). The crop received a total of 29 and $19 \mathrm{~mm}$ rainfall in Gaibandha and 120 and $42 \mathrm{~mm}$ rainfall in Rangpur (Figure 1c,d). Before conducting the experiment in the field, pre-planted soil samples were collected to a depth of $15 \mathrm{~cm}$ in both locations and analyzed in the SRDI (Soil Resource Development Institute) laboratory. Soil properties were presented of the site shown in Table 1.

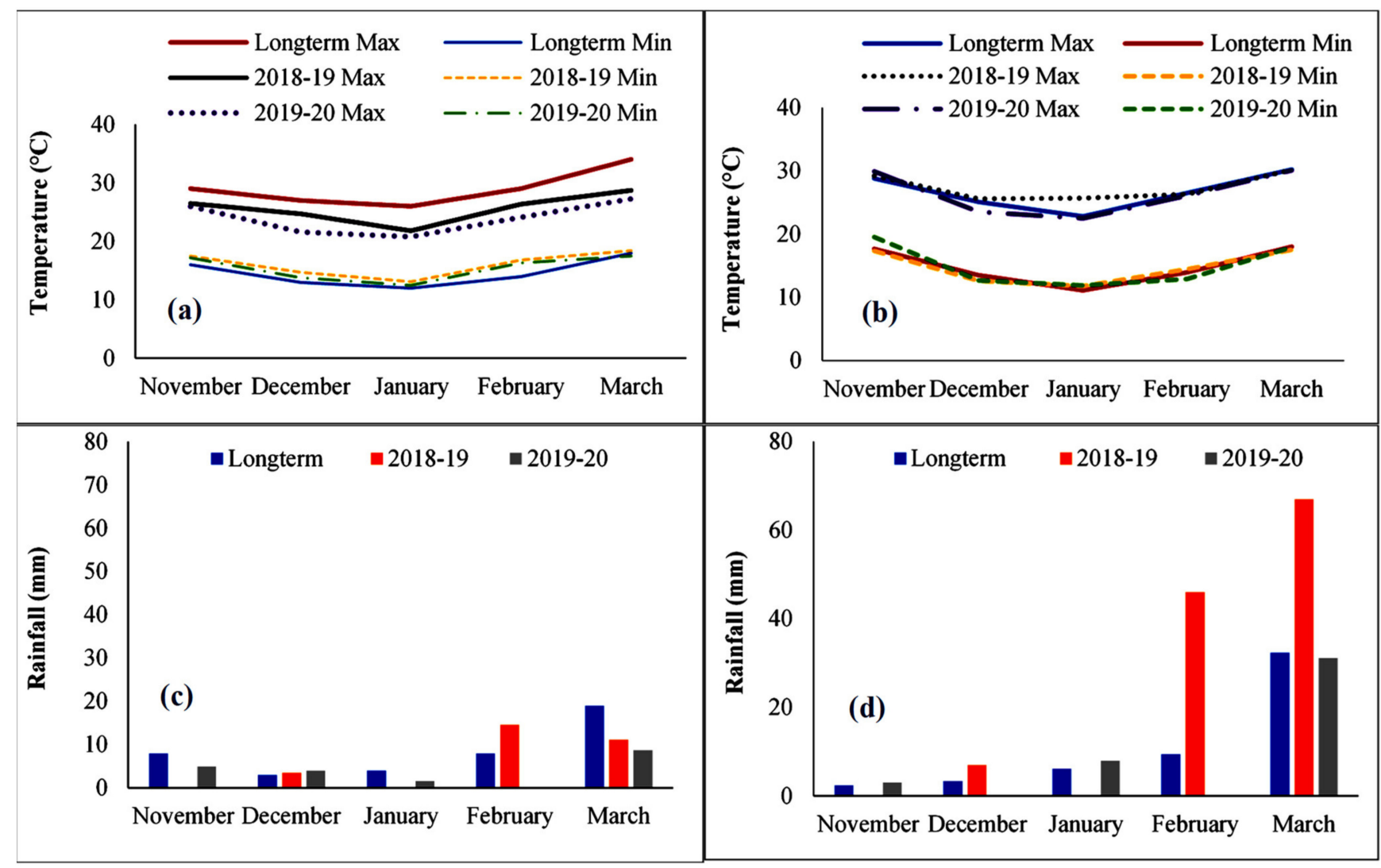

Figure 1. Monthly average maximum and minimum temperature of (a) Saghata, Gaibandha, and (b) Pirganj, Rangpur; (c) monthly mean rainfall (mm) of Saghata, Gaibandha, and (d) monthly mean rainfall (mm) of Pirganj, Rangpur, during two years compared to long-term (2000-2019) standards at Bangladesh Meteorological Department.

Table 1. Initial soil condition $(0-15 \mathrm{~cm})$ of OFSP trial plots at Saghata of Gaibandha and Pirganj of Rangpur in Bangladesh.

\begin{tabular}{|c|c|c|c|c|c|c|c|c|}
\hline \multirow{2}{*}{ Locations } & \multirow{2}{*}{$\mathrm{pH}$} & \multirow{2}{*}{ OM (\%) } & \multirow{2}{*}{ Total N (\%) } & \multirow{2}{*}{$\begin{array}{c}\mathrm{K} \\
\mathrm{meq} / 100 \mathrm{~g}\end{array}$} & $\mathbf{P}$ & $\mathbf{S}$ & $\mathrm{Zn}$ & B \\
\hline & & & & & \multicolumn{4}{|c|}{$\mu g / g$ Soil } \\
\hline \multirow{2}{*}{ Saghata, Gaibandha } & 6.45 & 0.83 & 0.05 & 0.14 & 9.68 & 15.2 & 0.24 & 0.25 \\
\hline & Slightly Acidic & VL & $\mathrm{L}$ & $\mathrm{M}$ & $\mathrm{L}$ & $\mathrm{M}$ & VL & $\mathrm{L}$ \\
\hline \multirow{2}{*}{ Pirganj, Rangpur } & 6.40 & 0.27 & 0.02 & 0.26 & 30.10 & 2.18 & 0.45 & 0.12 \\
\hline & Slightly Acidic & VL & VL & $\mathrm{M}$ & $\mathrm{VH}$ & VL & VL & VL \\
\hline
\end{tabular}

Very low $=$ VL; Low $=\mathrm{L} ;$ Medium $=\mathrm{M}$ and Very high $=\mathrm{VH}$.

\subsection{Planting Materials, Design of the Experiment, and Crop Management}

The trials were laid out at the farm level by following a randomized complete block design with six dispersed replications. Four BARI-released, vitamin-A enriched sweet potato cultivars were used, viz., BARI SP-8, BARI SP-12, BARI SP-14 and BARI SP-15, along with one local cultivar as a check (Table 2). 
Table 2. Major Characteristics and year release of OFSP varieties used in the trial during both crop seasons.

\begin{tabular}{|c|c|c|c|}
\hline $\begin{array}{l}\text { Name of the } \\
\text { Variety/Cultivar }\end{array}$ & Pedigree & $\begin{array}{l}\text { Year of } \\
\text { Release }\end{array}$ & Characteristics \\
\hline $\begin{array}{l}\text { BARI Mistialu-8 } \\
\text { (BARI SP-8) }\end{array}$ & CIP-440025 & 2008 & $\begin{array}{l}\text { Skin color: Red, Flesh color: Yellow, Dry matter: } 33.71 \pm 1 \% \text {, } \\
\text { Beta-carotene: } 1.08 \mathrm{mg} / 100 \mathrm{~g} \text { FW }{ }^{*}, \text { Fe: } 7.86 \mathrm{mg} / \mathrm{kg}, \mathrm{Zn}: 14.76 \mathrm{mg} / \mathrm{kg}\end{array}$ \\
\hline $\begin{array}{l}\text { BARI Mistialu-12 } \\
\text { (BARI SP-12) }\end{array}$ & CIP-440001 & 2013 & $\begin{array}{l}\text { Skin color: Yellow, Flesh color: Orange, Dry matter: } 22.04 \pm 1 \% \text {, } \\
\text { Beta-carotene: } 3.60 \mathrm{mg} / 100 \mathrm{~g} \text { FW }{ }^{*}, \text { Fe: } 14.76 \mathrm{mg} / \mathrm{kg}, \mathrm{Zn}: 8.09 \mathrm{mg} / \mathrm{kg}\end{array}$ \\
\hline $\begin{array}{l}\text { BARI Mistialu-14 } \\
\text { (BARI SP-14) }\end{array}$ & CIP-441132 & 2017 & $\begin{array}{l}\text { Skin color: Light orange, Flesh color: Orange, Dry matter: } 29.46 \pm 1 \% \text {, } \\
\text { Beta-carotene: } 10.10 \mathrm{mg} / 100 \mathrm{~g} \mathrm{FW} * \text {, Fe: } 5.17 \mathrm{mg} / \mathrm{kg}, \mathrm{Zn}: 6.47 \mathrm{mg} / \mathrm{kg}\end{array}$ \\
\hline $\begin{array}{l}\text { BARI Mistialu-15 } \\
\text { (BARI SP-15) }\end{array}$ & CIP-440267.2 & 2017 & $\begin{array}{l}\text { Skin color: Pink, Flesh color: Orange, Dry matter: } 28.91 \pm 1 \% \text {, } \\
\text { Beta-carotene: } 10.39 \mathrm{mg} / 100 \mathrm{~g} \mathrm{FW}{ }^{*}, \mathrm{Fe}: 13.25 \mathrm{mg} / \mathrm{kg}, \mathrm{Zn}: 6.47 \mathrm{mg} / \mathrm{kg}\end{array}$ \\
\hline Local Variety & $\begin{array}{l}\text { Local } \\
\text { cultivar }\end{array}$ & - & $\begin{array}{c}\text { Skin color: Pink, Flesh color: White, } \\
\text { Dry matter: } 36.5 \pm 1 \% \text {, Beta-carotene: Trace/nil }\end{array}$ \\
\hline
\end{tabular}

* FW means fresh weight.

Sweet potato vines were planted between 1-10 November in both crop years over the two locations, with the spacing $60 \mathrm{~cm}$ across row and $30 \mathrm{~cm}$ within row. Unit plot size ranged from 200 to $400 \mathrm{~m}^{2}$ across the locations. The trial plot area was fertilized with $120 \mathrm{~kg} \mathrm{~N} \mathrm{ha}^{-1}$ as urea, $30 \mathrm{~kg} \mathrm{P} \mathrm{ha}^{-1}$ as triple superphosphate (TSP), $60 \mathrm{~kg} \mathrm{~K} \mathrm{ha}^{-1}$ as muriate of potash (MoP), $15 \mathrm{~kg} \mathrm{Sha}^{-1}$ as gypsum $4 \mathrm{~kg} \mathrm{Zn} \mathrm{ha}^{-1}$ as zinc sulfate (and $1 \mathrm{~kg} \mathrm{~B} \mathrm{ha}^{-1}$ as boric acid. The $50 \%$ of the urea and MoP with the whole amount of TSP, gypsum, zinc sulfate and boric acid were applied during the final land preparation. The remaining urea and $\mathrm{MoP}$ were applied at $35 \mathrm{DAP}$ (days after planting). For good crop stand and higher root yield, irrigation was applied at 30, 45, 60, 75, 90, $115 \mathrm{DAP}$, maintaining two-third $(6 \mathrm{~cm})$ of the valley in both locations.

Some infestation of weevil occurred in the vines in both locations during vine preparation. The weevil infestation in the vines of potatoes was controlled by dipping the vines in the Ripcord (Cypermethrin) solution before planting and also were applied (at $60 \mathrm{DAP}$ as well as earthing up (30,60 and 90 DAP). The crops were harvested on 25 to 30 March each

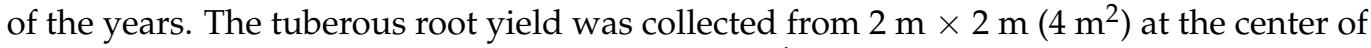
the plot at each location and converted into $\mathrm{tha}^{-1}$. Ten plants were randomly selected, and the tuberous roots number plant ${ }^{-1}$ was averaged. Similarly, the length of root $(\mathrm{cm})$, the diameter of root $(\mathrm{cm})$, and per plant root weight were also measured following the same procedure.

\subsection{Calculation of Root Dry Yield $\left(t h a^{-1}\right)$}

For dry matter measurement, about $100 \mathrm{~g}$ of sweet potato was collected for each variety and was oven-dried for about $24 \mathrm{~h}$ at $80^{\circ} \mathrm{C}$. Finally, the amount of root dry matter $(\%)$ was determined using the following equation:

$$
\text { Dry matter }(\%)=\text { Sample dry weight } / \text { Total sample weight } \times 100
$$

The dry root yield of sweet potato was calculated from the fresh tuberous root yield and $\%$ dry matter content using the formula:

Dry tuberous root yield $\left(\mathrm{t} \mathrm{ha}^{-1}\right)=$ fresh root yield $\left(\mathrm{t} \mathrm{ha}^{-1}\right) \times \%$ dry matter content $/ 100$

\section{4. $\beta$-Carotene Yield Calculation ( $\mathrm{kg} \mathrm{ha}^{-1}$ )}

The cut roots were collected in a compound stack and five root samples (weighing 100 to $300 \mathrm{~g}$ ) were taken to determine b-carotene. The cut roots were washed and cleaned in tap water and allowed to air dry. Dried roots were peeled, and every root was slashed longitudinal direction in four parts. Two parallel sections of individual roots were taken to prepare for the 100-g compound sample which was placed in a transparent polythene bag and freeze-dried at $-31^{\circ} \mathrm{C}$ for $72 \mathrm{~h}$. The dried samples were weighed, ground into flour 
in a stainless-steel mill, and stored in brown paper bags. The amount of root dry matter was computed from flesh and dry weight and expressed as a percentage. About $2 \mathrm{~g}$ of ground sweet potato sample was taken with $5 \mathrm{ml}$ acetone and then acetone-petroleum ether $(20: 80 ; v / v)$ was added. After filtration and rotational evaporation process at $35^{\circ} \mathrm{C}$, the remaining solvent was removed to $\mathrm{N}_{2}$ atmosphere and then dissolved in $2 \mathrm{ml}$ petroleum ether. $\beta$-carotene (Sigma-Aldrich Corp., St. Louis, USA) stock and standard solutions and sample solutions measured $450 \mathrm{~nm}$ on spectrophotometer [26].

\subsection{Economic Performance}

The variable costs used in the analysis include land preparation, cutting of vines, planting of vines in the main field, fertilizers, insecticides, irrigation, harvesting and cleaning, etc. (Table 3).

Table 3. The production cost of sweet potato used in the economic analysis.

\begin{tabular}{|c|c|c|c|c|}
\hline Items & Amount ha- ${ }^{-1}$ & Unit Price (US\$) & Total Cost (US\$) & $\%$ of Total \\
\hline - Variable costs & & & & \\
\hline - $\quad$ Vine $\left(\right.$ No. ha $\left.{ }^{-1}\right)$ & 56,000 & 0.006 & 336 & 24.47 \\
\hline - Land preparation & 1 & 84 & 84 & 6.12 \\
\hline - Human labor (Man-days) & & & & 0.00 \\
\hline - Vine cutting & 10 & 4.8 & 48 & 3.50 \\
\hline - Vine plantation & 28 & 4.8 & 134 & 9.76 \\
\hline - $\quad$ Fertilizer & 2 & 4.8 & 10 & 0.73 \\
\hline - Irrigation & 8 & 4.8 & 38 & 2.77 \\
\hline - Weeding & 15 & 4.8 & 72 & 5.24 \\
\hline - Insecticide & 3 & 4.8 & 14 & 1.02 \\
\hline - Harvesting and cleaning & 30 & 4.8 & 144 & 10.49 \\
\hline - $\quad$ Total labor & 96 & & 461 & 33.58 \\
\hline - $\quad$ Fertilizer & & & & 0.00 \\
\hline - $\quad$ Urea $(\mathrm{kg})$ & 260 & 0.192 & 50 & 3.64 \\
\hline • $\quad$ TSP $(\mathrm{kg})$ & 150 & 0.264 & 40 & 2.91 \\
\hline - $\quad \mathrm{MoP}(\mathrm{kg})$ & 120 & 0.18 & 22 & 1.60 \\
\hline - $\quad$ Gypsum $(\mathrm{kg})$ & 83 & 0.12 & 10 & 0.73 \\
\hline - $\quad$ Zinc sulphate $(\mathrm{kg})$ & 10 & 1.8 & 18 & 1.31 \\
\hline - $\quad$ Boric acid $(\mathrm{kg})$ & 6 & 1.44 & 9 & 0.66 \\
\hline - Irrigation & 1 & 90 & 90 & 6.55 \\
\hline - Insecticide & 1 & 60 & 60 & 4.37 \\
\hline - Total variable cost & & & 1179 & 85.87 \\
\hline - $\quad$ Fixed Cost & & & & 0.00 \\
\hline - Interest on operating capital (\%) & 0.09 & & 44 & 3.20 \\
\hline - $\quad$ Land rental value & 1 & 360 & 150 & 10.92 \\
\hline - $\quad$ Total fixed cost & & & 194 & 14.13 \\
\hline - $\quad$ Total cost & & & 1373 & \\
\hline
\end{tabular}

These variable costs were determined based on information provided by local farmers in the communities surrounding the trials. Fixed costs are costs that do not change with the change in the amount and type of production, for example, the price of land rent, and interest on operating costs. The land rental price includes the rental cost for sweet potato production based on information provided by local farmers. The cost of land rent was 
determined according to the duration of the crop (5 months). Interest on Operating Capital (IOC) was determined by [27] the following equation:

$$
\text { Interest on operating capital }(\mathrm{IOC})=\mathrm{TVC} \times \mathrm{I} \times \mathrm{t} /(100 \times 12)
$$

where TVC $=$ total variable cost, $\mathrm{I}=$ interest rate per annum $(9 \%$, at present the interest rate of the bank in Bangladesh) and $t=$ crop production period in months (like above).

The total cost in sweet potato production was estimated by the sum of total variable cost and fixed costs. The price of inputs and outputs were estimated in local currency (Bangladeshi Taka, BDT) based on the average values in the respective areas (Gaibandha and Rangpur). The above prices were converted to US\$ using an exchange rate of 1 US\$ $=84.69$ BDT. The total (gross) return was estimated from the quantity of harvested tuberous root $\left(\mathrm{t} \mathrm{ha}^{-1}\right)$ and the price of their farm-gate. The prices of sweet potatoes were $142 \mathrm{US} \mathrm{t}^{-1}$. The gross margin was estimated from the difference between gross return and total variable cost. The net return was determined from the difference between gross return and total cost. Finally, the benefit-cost ratio (BCR) was estimated from gross return divided by total cost.

Preliminary information was collected by personal interview (PI), key informant interview (KII) and focus group discussion (FGD). It was organized by assigning a sorted, open, and closed-end questionnaire and a checklist. Sweet potato farmers were interviewed directly by enumerators to collect preliminary data on sweet potato growers and yields. Most of the tabular analysis was conducted with mean and percentage calculations

The profit margin of sweet potato growers, traders and retailers were estimated using the following formula:

$$
\mathrm{NP}=\mathrm{TR}-\mathrm{TC}
$$

where NP = Net Profit (US\$), TR = Total Return (US\$) and TC = Total cost.

\subsection{Statistical Analysis}

Data on different attributes recorded for two years were analyzed by ANOVA (using STAR' statistical package developed by Biometrical Division, International Rice Research Institute (IRRI), Manila, Philippines) two evaluate the differences between treatments and the means were separated using LSD (least significant difference) at $5 \%$ level of significance. The results of different attributes with their interactions were found statistically significant and have been presented accordingly. Again, the stability parameter was analyzed using "metan" statistical package [28] in R studio version 1.4.110.

\section{Results}

3.1. Impact of OFSP Variety, Year and Location on Yield-Related Characters, Fresh and Dry Root Yield, and Beta-Carotene Production in the Northern Riverbanks

The main effect and interaction effects of the factors (sweet potato varieties, locations and years) on various yield contributing characters (tuberous roots plant ${ }^{-1}$; Tuberous roots length; Tuberous root diameter; Root yield plant $^{-1}$ ) are presented in Table 4 . The average tuberous root plant ${ }^{-1}$ of sweet potato varieties were ranged from 3.29 to 5.16 plant $^{-1}$ where the lowest tuberous root was observed in the local variety and the highest was from BARI SP-12 which was similar to BARI SP-8 and BARI SP-14 (Table 4). Compared to local varieties, OFSP varieties, BARI SP-8, BARI SP-12, BARI SP-14 and BARI SP-15 produced an average of $54.71 \%, 56.83 \%, 46.50 \%$ and $37.08 \%$ more tuberous roots plant $^{-1}$, respectively. The present findings agree with previous findings $[29,30]$ and the variation in tuberous roots plant ${ }^{-1}$ was genotypic. 
Table 4. Effect of Variety, environment, and growing season on no. of tuberous roots plant ${ }^{-1}$, length of root, the diameter of root and tuberous root yield plant $^{-1}$.

\begin{tabular}{|c|c|c|c|c|}
\hline Treatment & No. of Tuberous Root Plant ${ }^{-1}$ & Length of Root (cm) & Diameter of Root (cm) & $\begin{array}{c}\text { Tuberous Root Weight } \\
\text { Plant }^{-1}(\mathrm{~g})\end{array}$ \\
\hline \multicolumn{5}{|c|}{ Variety $(\mathrm{V})$} \\
\hline BARI SP-8 & $5.09(54.71 \%)$ & $15.19(23.10 \%)$ & $4.34(52.28 \%)$ & $463.71(65.33 \%)$ \\
\hline BARI SP-12 & $5.16(56.83 \%)$ & $15.34(24.31 \%)$ & $4.21(47.72 \%)$ & $491.81(75.35 \%)$ \\
\hline BARI SP-14 & $4.82(46.50 \%)$ & $14.62(18.48 \%)$ & $3.96(38.95 \%)$ & $443.61(58.17 \%)$ \\
\hline BARI SP-15 & $4.51(37.08 \%)$ & $15.08(22.20 \%)$ & $3.85(35.09 \%)$ & $430.51(53.50 \%)$ \\
\hline Local & 3.29 & 12.34 & 2.85 & 280.47 \\
\hline $\mathrm{LSD}_{0.05}$ & 0.42 & 1.29 & 0.36 & 27.38 \\
\hline \multicolumn{5}{|c|}{ Environment (E) } \\
\hline Gaibandha & 4.52 & 14.47 & 3.82 & 418.77 \\
\hline Rangpur & 4.63 & 14.55 & 3.88 & 425.27 \\
\hline $\mathrm{LSD}_{0.05}$ & ns & ns & ns & ns \\
\hline \multicolumn{5}{|c|}{ Year $(\mathrm{Y})$} \\
\hline 2018-2019 & 4.64 & 14.26 & 3.81 & 411.26 \\
\hline 2019-2020 & 4.52 & 14.76 & 3.88 & 432.78 \\
\hline $\mathrm{LSD}_{0.05}$ & ns & ns & ns & 27.38 \\
\hline
\end{tabular}

Values within the parenthesis indicate the values increased (\%) over check; V, Variety, E, Environment (locations) and Y, Year; ns: non-significant; $\mathrm{LSD}_{0.05}$ means significant at $5 \%$ level of probability.

Considering the two-year average data, the tuberous root length of sweet potato varieties ranged from 12.42 to $15.42 \mathrm{~cm}$ and 12.25 to $14.96 \mathrm{~cm}$ in Gaibandha and Rangpur, respectively (Table 5). In Gaibandha, the highest root length $(15.42 \mathrm{~cm})$ was attained from BARI SP-8 and BARI SP-12 which was identical to BARI SP-14 $(15.16 \mathrm{~cm})$. Again, in Rangpur, the highest root length was attained from BARI SP-15 $(16.22 \mathrm{~cm})$ followed by BARI SP-12 $(15.26 \mathrm{~cm})$ and BARI SP-8 $(14.96 \mathrm{~cm})$. In both locations, the lowest root length was attained from the local variety with a value of 12.42 and $12.25 \mathrm{~cm}$, respectively. Average root length was attained from OFSP varieties, 23.10\% from BARI SP-8, 24.31\% from BARI SP-12, 18.48\% from BARI SP-14, and 22.20\%, respectively (Table 5).

Table 5. Interaction effect of variety (V) and environment $(E)$ on root length of sweet potato.

\begin{tabular}{cccc}
\hline \multirow{2}{*}{ Variety (V) } & \multicolumn{2}{c}{ Environment/Locations } & Mean Increased over \\
\cline { 2 - 3 } & Gaibandha & Rangpur & 23.10 \\
BARI SP-8 & 15.42 & 14.96 & 24.36 \\
BARI SP-12 & 15.42 & 15.26 & 18.48 \\
BARI SP-14 & 15.16 & 14.07 & 22.20 \\
BARI SP-15 & 13.93 & 16.22 & - \\
Local & 12.42 & 12.25 & \\
\hline LSD & 1.05 &
\end{tabular}

Average of two-year data across locations, the tuberous root diameter of sweet potato varieties ranged from 2.85 to $4.34 \mathrm{~cm}$ where BARI SP-8 attained the maximum root diameter trailed by BARI SP-12 and BARI SP-14. Compared to local varieties, OFSP varieties, BARI SP-8, BARI SP-12, BARI SP-14, and BARI SP-15 produced an average of $52.28 \%, 47.72 \%$, $38.95 \%$, and $35.09 \%$ more tuberous root diameter, respectively. All-time low root diameter was attained from the local variety. In Rangpur, the average root yield plant ${ }^{-1}$ among the sweet potato genotypes varied from 274.4 to $509.9 \mathrm{~g} \mathrm{plant}^{-1}$ and in Gaibandha it was from 286.5 to $473 \mathrm{~g} \mathrm{plant}^{-1}$ (Table 6). Considering the mean of the two years, BARI SP-12 was the highest yielding followed by BARI SP-8. The local cultivar (check) produced the lowest 
root yield plant ${ }^{-1}$ in both locations. The average root yield plant ${ }^{-1}$ of typical sweet potato genotypes were varied from 280.4 to $491.8 \mathrm{~g}$ plant $^{-1}$ where BARI SP-12 was the highest yielding followed by BARI SP-8 and BARI SP-14 (Table 4). Compared to local varieties, BARI SP-8, BARI SP-12, BARI SP-14 and BARI SP-15 produced an average of $65.33 \%$, $75.35 \%, 58.17 \%$ and $53.50 \%$ more tuberous roots weight plant $^{-1}$, respectively. Considering the crop season, average more root was produced in 2019-2020 compared to 2018-2019 crop season and considering the location mean, more root was produced in Rangpur than Gaibandha (Table 6).

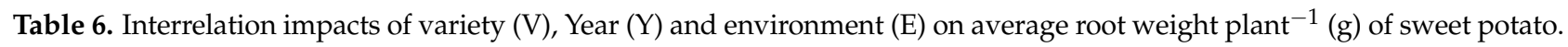

\begin{tabular}{ccccccc}
\hline \multirow{2}{*}{ Varieties (V) } & \multicolumn{3}{c}{ Gaibandha } & \multicolumn{3}{c}{ Rangpur } \\
\cline { 2 - 7 } & $\mathbf{2 0 1 8 - 2 0 1 9}$ & $\mathbf{2 0 1 9 - 2 0 2 0}$ & Mean & 2018-2019 & 2019-2020 & Mean \\
\hline BARI SP-8 & 464.19 & 474.29 & $469.24(63.77 \%)$ & 423.68 & 492.66 & $458.17(66.96 \%)$ \\
BARI SP-12 & 444.97 & 502.39 & $473.68(65.32 \%$ & 502.01 & 517.87 & $509.94(85.82 \%)$ \\
BARI SP-14 & 428.67 & 449.37 & $439.02(53.22 \%)$ & 440.24 & 456.15 & $448.20(63.33 \%)$ \\
BARI SP-15 & 420.96 & 429.8 & $425.38(48.46 \%)$ & 432.05 & 439.22 & $435.64(58.75 \%)$ \\
Local & 282.73 & 290.3 & 286.52 & 273.13 & 275.71 & 274.42 \\
\hline LSD $_{0.05}$ & & & 27.38 & & \\
\hline
\end{tabular}

$\mathrm{LSD}_{0.05}$, significant at $5 \%$ level of probability.

The main effect and interaction effects of the factors (sweet potato varieties, locations and years) on various fresh root yields, dry root yield and beta-carotene yield were presented in Tables 7-9. Fresh tuberous root yield of different sweet potato genotypes in Gaibandha was ranged from 18.91 to $31.89 \mathrm{t} \mathrm{ha}^{-1}$ where BARI SP-8 was the highest yielding and BARI SP-12 was the 2nd highest yielding.

Table 7. Fresh and dry root yield $\left(\mathrm{tha}^{-1}\right)$, beta carotene yield $\left(\mathrm{kg} \mathrm{ha}^{-1}\right)$ of sweet potato varieties.

\begin{tabular}{|c|c|c|c|}
\hline Treatment & $\begin{array}{l}\text { Yield of Fresh Roots } \\
\qquad\left(t h a^{-1}\right)\end{array}$ & $\begin{array}{l}\text { Yield of Dry Roots } \\
\left(\mathrm{t} \mathrm{ha} \mathbf{a}^{-1)}\right.\end{array}$ & $\begin{array}{c}\text { Beta Carotene Yield } \\
\left(\mathrm{kg} \mathrm{ha}^{-1}\right) \text { (DW Basis) }\end{array}$ \\
\hline \multicolumn{4}{|l|}{ Variety (V) } \\
\hline BARI SP-8 & $31.07(67.86 \%)$ & $10.47(66.99 \%)$ & 336.19 \\
\hline BARI SP-12 & $32.00(72.88 \%)$ & $7.05(12.44 \%)$ & 1152.29 \\
\hline BARI SP-14 & $29.28(58.18 \%)$ & $8.62(37.48 \%)$ & 2955.90 \\
\hline BARI SP-15 & $28.41(53.48 \%)$ & $8.21(30.94 \%)$ & 2951.41 \\
\hline Local & 18.51 & 6.27 & Nil \\
\hline $\mathrm{LSD}_{0.05}$ & 1.27 & 0.38 & 59.49 \\
\hline \multicolumn{4}{|c|}{ Environment (E) } \\
\hline Gaibandha & 27.64 & 8.10 & 1463.97 \\
\hline Rangpur & 28.07 & 8.15 & 1510.26 \\
\hline $\mathrm{LSD}_{0.05}$ & ns & ns & 37.63 \\
\hline \multicolumn{4}{|l|}{ Year (Y) } \\
\hline 2018-2019 & 27.14 & 7.91 & 1460.16 \\
\hline 2019-2020 & 28.56 & 8.34 & 1514.07 \\
\hline $\mathrm{LSD}_{0.05}$ & 1.27 & 0.38 & 37.63 \\
\hline
\end{tabular}

Values within the parenthesis indicate the values increased (\%) over check; V, Variety, E, Environment (locations) and Y, Year; ns: non-significant; $\mathrm{LSD}_{0.05}$ means significant at $5 \%$ level of probability. 
Table 8. Interrelation impacts of variety $(\mathrm{V})$, and environment $(\mathrm{E})$ on fresh yield $\left(\mathrm{t} \mathrm{ha}{ }^{-1}\right)$ and dry yield $\left(\mathrm{t}\right.$ ha $\left.{ }^{-1}\right)$ of sweet potato.

\begin{tabular}{|c|c|c|c|c|c|c|}
\hline \multirow{2}{*}{ Variety (V) } & \multicolumn{2}{|c|}{$\begin{array}{l}\text { Yield of Fresh Roots } \\
\left(t h^{-1}\right)\end{array}$} & \multirow{2}{*}{$\begin{array}{c}\% \text { Yield } \\
\text { Increase over } \\
\text { Local Check }\end{array}$} & \multicolumn{2}{|c|}{$\begin{array}{l}\text { Yield of Dry Roots } \\
\qquad\left(t \mathrm{ha}^{-1}\right)\end{array}$} & \multirow{2}{*}{$\begin{array}{c}\% \text { Yield } \\
\text { Increase over } \\
\text { Local Check }\end{array}$} \\
\hline & Gaibandha & Rangpur & & Gaibandha & Rangpur & \\
\hline BARI SP-8 & 31.89 & 30.24 & 67.86 & 10.75 & 10.20 & 66.99 \\
\hline BARI SP-12 & 30.34 & 33.66 & 72.88 & 6.69 & 7.42 & 12.44 \\
\hline BARI SP-14 & 28.98 & 29.58 & 58.18 & 8.54 & 8.71 & 37.48 \\
\hline BARI SP-15 & 28.08 & 28.75 & 53.51 & 8.12 & 8.31 & 30.94 \\
\hline Local & 18.91 & 18.11 & & 6.40 & 6.13 & \\
\hline $\mathrm{LSD}_{0.05}(\mathrm{~V} \times \mathrm{E})$ & \multicolumn{2}{|c|}{1.27} & \multicolumn{4}{|c|}{0.38} \\
\hline
\end{tabular}

V, Variety, E, Environment (locations) and Y, Year; LSD $_{0.05}$ means significant at 5\% level of probability.

Table 9. Interrelation impacts of variety $(\mathrm{V})$, and year $(\mathrm{Y})$ on fresh yield $\left(\mathrm{t} \mathrm{ha}^{-1}\right)$ and dry yield $\left(\mathrm{t} \mathrm{ha} \mathrm{a}^{-1}\right.$ ) of sweet potato.

\begin{tabular}{|c|c|c|c|c|c|c|}
\hline \multirow{2}{*}{ Variety (V) } & \multicolumn{2}{|c|}{$\begin{array}{l}\text { Yield of Fresh Roots } \\
\qquad\left(t \mathbf{h a}^{-1}\right)\end{array}$} & \multirow{2}{*}{$\begin{array}{c}\% \text { Yield } \\
\text { Increase over } \\
\text { Local Check }\end{array}$} & \multicolumn{2}{|c|}{$\begin{array}{l}\text { Yield of Dry Roots } \\
\qquad\left(t \mathrm{ha}^{-1}\right)\end{array}$} & \multirow{2}{*}{$\begin{array}{c}\% \text { Yield } \\
\text { Increase over } \\
\text { Local Check }\end{array}$} \\
\hline & 2018-2019 & 2019-2020 & & 2018-2019 & 2019-2020 & \\
\hline BARI SP-8 & 29.30 & 32.84 & 67.86 & 9.88 & 11.07 & 66.99 \\
\hline BARI SP-12 & 31.25 & 32.74 & 72.88 & 6.89 & 7.22 & 12.44 \\
\hline BARI SP-14 & 28.67 & 29.88 & 58.18 & 8.45 & 8.80 & 37.48 \\
\hline BARI SP-15 & 28.15 & 28.68 & 53.51 & 8.14 & 8.29 & 30.94 \\
\hline Local & 18.34 & 18.68 & & 6.21 & 6.32 & \\
\hline $\mathrm{LSD}_{0.05}(\mathrm{~V} \times \mathrm{E})$ & \multicolumn{2}{|c|}{1.27} & \multicolumn{4}{|c|}{0.38} \\
\hline
\end{tabular}

V, Variety, E, Environment (locations) and Y, Year; LSD $_{0.05}$ means significant at $5 \%$ level of probability.

In Rangpur, the fresh root yield among the sweet potato genotypes ranged from 18.11 to $30.24 \mathrm{t} \mathrm{ha}^{-1}$, where BARI SP-12 was the highest yielding and BARI SP-8 was the 2nd highest yielding. On the contrary, the local cultivar (check) generated the lowest root yield in Gaibandha and Rangpur 18.91 and $18.11 \mathrm{t} \mathrm{ha}^{-1}$, respectively. In the 2018-2019 crop season, BARI SP-12 was the highest root yielding $\left(31.25 \mathrm{t} \mathrm{ha}^{-1}\right)$ trailed by BARI SP-8 (29.30) and in 2019-2020 crop season BARI SP-8 was the highest fresh root yielder $\left(32.84 \mathrm{t} \mathrm{ha}^{-1}\right)$ which was identical as BARI SP-12 (31.74 $\left.\mathrm{tha}^{-1}\right)$ followed by BARI SP-14 and BARI SP-15. The local cultivar was the lowest yielding in a couple of years $\left(18.34 \mathrm{t} \mathrm{ha}^{-1}\right.$ and $18.66 \mathrm{tha}^{-1}$. Considering the mean of both years results across locations the uppermost fresh tuberous root yield ( $\left.32.00 \mathrm{t} \mathrm{ha}^{-1}\right)$ was attained from BARI SP-12 and the 2nd uppermost was from BARI SP-8 $\left(31.07 \mathrm{tha}^{-1}\right)$ and the 3rd uppermost yield was from BARI SP-14 $\left(29.28 \mathrm{t} \mathrm{ha}^{-1}\right)$ which was $72.88 \%, 67.86 \%$, and $58.18 \%$ higher fresh root yield ha ${ }^{-1}$, respectively, compared to local cultivar (Tables 7-9). The lowest mean fresh root yield was attained from the local variety (18.51 t ha ${ }^{-1}$ ) in Rangpur (Table 8).

Root dry yield of different sweet potato genotypes in Gaibandha was ranged from 6.40 to $11.75 \mathrm{t} \mathrm{ha}^{-1}$ where BARI SP-8 produced the maximum dry yield followed by BARI SP-14 and BARI SP-15. Similar dry root yield among the genotypes was also observed in Rangpur and was ranged from 6.13 to $10.19 \mathrm{t} \mathrm{ha}^{-1}$, where BARI SP-8 was the highest dry root yielder followed by BARI SP-14 and BARI SP-15. Local variety (check) produced the lowest dry root yield in Gaibandha and Rangpur 6.40 and $6.13 \mathrm{t} \mathrm{ha}^{-1}$, respectively. In both years, BARI SP-8 remained the highest dry root yielder (9.87 and $11.07 \mathrm{tha}^{-1}$ in 2018-2019 and 2019-2020 crop season) followed by BARI SP-14 (8.44 and $8.88 \mathrm{t} \mathrm{ha}^{-1}$ ) and BARI SP-15 (8.13 and 8.29). The local cultivar proved to be the lowest dry root yielder in a couple of years $\left(6.20\right.$ and $\left.6.26 \mathrm{t} \mathrm{ha}^{-1}\right)$. Reflecting the average of two years results across locations the BARI SP-8 attained the highest dry root yield $\left(10.47 \mathrm{t} \mathrm{ha}^{-1}\right)$ and BARI SP-14 $\left(8.62 \mathrm{t} \mathrm{ha}^{-1}\right)$ attained the 2nd highest, and BARI SP-15 $\left(8.21 \mathrm{t} \mathrm{ha}^{-1}\right)$ attained the 3rd highest dry yielder which produced $67.86 \%, 37.48 \%$, and $30.94 \%$ higher dry root yield $\left(\mathrm{t} \mathrm{ha}{ }^{-1}\right)$, respectively, in comparison with local cultivar. The lowest mean dry root yield was attained from the local cultivar $\left(6.26 \mathrm{t} \mathrm{ha}^{-1}\right)$. 
Yield $\left(\mathrm{Kg} \mathrm{ha}^{-1}\right)$ of $\beta$-Carotene (DW Basis)

$\beta$-Carotene production of different sweet potato genotypes was ranged from 335.53 to $2957.09 \mathrm{ha}^{-1}$ where BARI SP-14 was the average highest beta-carotene yielder, followed by BARI SP-15. BARI SP-12 and BARI SP- 8 was the lowest beat-carotene yielder, and no/trace beta-carotene yield was determined from the local cultivar (Table 7).

\subsection{Selection for Stable Sweet Potato Genotype Based on Stability Variance and AMMI Analysis}

The tuberous root yield stability for each variable across the location-year was stated by Shukla [31] and reported that varieties along with minimum values of Shukla's stability variance $\left(\sigma^{2} \mathrm{i}\right)$ are more stable. BARI SP-14 demonstrated the lowest Shukla's variance stability $(-0.41)$ that seemed to be more stable over the location-year effect. In addition. Shukla's stability variance $\left(\sigma^{2} \mathrm{i}\right)$ criteria are also suitable for the BARI SP-14. The genotypes BARI SP-8 (32.46 tha $\left.{ }^{-1}\right)$ and BARI SP-15 $\left(30.60 \mathrm{tha}^{-1}\right)$ produced a higher yield considering all years and locations (Tables 8 and 9 ).

Furthermore, the AMMI Stability value (ASV) is used to define genotype and location adaptability [32]. The genotypes with the maximum ASV value are taken into account unstable and more responsive to specific environments. On the other hand, the genotypes with the minimum ASV value are envisaged as stable genotypes over the environment (Table 10). The BARI SP-15 and BARI SP-14 genotypes were the best for yield and stability based on ASV value whereas the BARI SP-8 and BARI SP-12 showed the highest yield performance and were the most unstable based on ASV value.

Table 10. AMMI analysis provides stability parameters for tuber yield in sweet potato.

\begin{tabular}{ccccc}
\hline Variety & Mean & $\begin{array}{c}\text { Shukla's Stability } \\
\text { Variance }(\boldsymbol{\sigma} \mathbf{2 i})\end{array}$ & $\begin{array}{c}\text { AMMI-Stability Value } \\
\text { (ASV) }\end{array}$ & Note \\
\hline BARI SP-8 & 31.07 & 3.08 & 2.50 & Specific adaptation \\
BARI SP-12 & 32.00 & 3.33 & 2.84 & Specific adaptation \\
BARI SP-14 & 29.28 & -0.41 & 0.31 & Wider adaptation \\
BARI SP-15 & 28.42 & 0.01 & 0.55 & Wider adaptation \\
Local & 18.51 & 1.04 & 1.32 & Specific adaptation to the marginal environment \\
\hline
\end{tabular}

The principal component score (IPCA1) for both genotypes and environments were plotted against the mean tuber yield and the AMMI biplot1 was drawn (Figure 2A). The Principal Component interaction (IPCA1) score was plotted against the Principal Component interaction (IPCA2) for assessing the adaptation of genotypes (Figure 2B). The variety BARI SP-14 which is situated within the circle was stable and the other varieties were unstable because of their disperse position (Figure 2B).

\subsection{Profitability Analysis of OFSP at Farm Level in the Northern Riverbanks}

The summary statistics of survey variables of 80 sweet potato farms are presented in Table 11.

Table 11. Summary statistics for survey variables under different sweet potato varieties.

\begin{tabular}{ccccc}
\hline Variables & Sample Mean & $\begin{array}{c}\text { Standard } \\
\text { Deviation }\end{array}$ & Minimum & Maximum \\
\hline Gross Output (US Dollar) & 2133.40 & 238.05 & 1599.40 & 2828.51 \\
Land Size (hectares) & 0.43 & 1.05 & 0.11 & 1.09 \\
Labor (man-days) & 91.72 & 85.71 & 63.42 & 133.70 \\
Variable Cost (taka) & 805.43 & 525.39 & 547.51 & 1295.56 \\
Fixed Cost (taka) & 103.48 & 56.66 & 86.17 & 130.02 \\
Age (years) & 42.50 & 11.13 & 25.00 & 66.00 \\
Education (years) & 8.31 & 4.40 & 0.00 & 14.00 \\
\hline
\end{tabular}




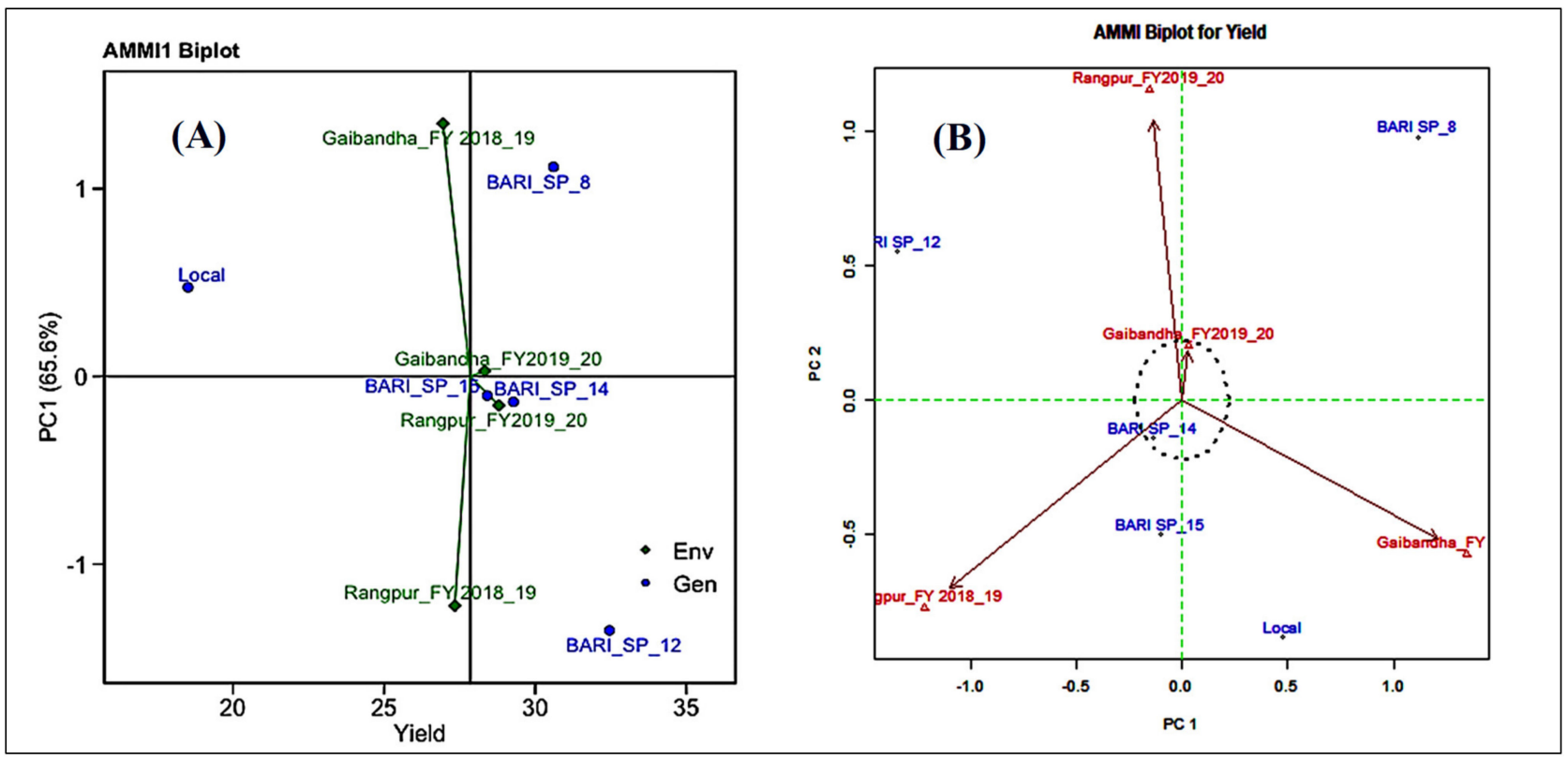

Figure 2. (A) AMMI 1 and (B) AMMI 2 biplot of IPCA1 (Interaction Principal Component Axes for genotype) axis against the mean yield of five sweet potato varieties evaluated in Gaibandha and Rangpur for tubers yield in sweet potato during 2018-2019 and 2019-2020 in Bangladesh.

The sample average gross output was 2133.40 US\$ with a standard deviation of 238.05 that indicated the large variability of output among the sweet potato farms. Variations of standard deviation for the entire variable were large due to variation of land size and the minimum land size of sweet potato farms was 0.11 and the maximum was 1.09. Human labor was employed 91.72 US\$ per farm for producing the crop in the crop year (2018-2019). It indicated that the existing production technology among farm households was labor intensive. The variable cost involved among the cost of inputs of the sample farms, e.g., seed cost, hired labor, manure, fertilizer, insecticide, irrigation, etc. Conversely, fixed labor involved the rental value of land and family labor. Age and education are important socioeconomic factors that keep a great role in the on-farm operation. The OFSP regarding all the varieties were made at a profit with positive gross margin, net return and $B C R>1$, whatever the amount of labor cost in the economic analysis (Table 12). The gross margin was $97-132 \%$ higher (1406-1914 US\$ ha ${ }^{-1}$ ) than that of the local sweet potato variety (1450 US\$ ha ${ }^{-1}$ ) due to higher tuberous root yield (53-73\%) with the same production costs. Net return

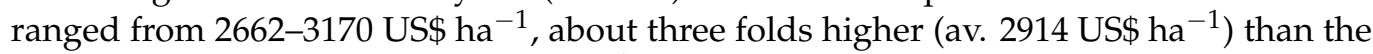
local sweet potato variety (1256 US\$ ha ${ }^{-1}$ ). Finally, the BCR in OFSP ranged from 2.94-3.31, while the minimum value was observed in the local variety (1.91).

Table 12. Economic profitability of OFSP. Data are presented mean \pm standard error in US\$ (1 US\$ $=84.69$ BDT).

\begin{tabular}{|c|c|c|c|c|c|c|c|c|}
\hline Varieties & $\begin{array}{l}\text { Yield } \\
\left(t_{\text {h }} \mathbf{a}^{-1}\right)\end{array}$ & $\begin{array}{c}\text { Gross } \\
\text { Return } \\
\left(\mathrm{US} \$ \mathrm{ha}^{-1}\right)\end{array}$ & $\begin{array}{c}\text { Total } \\
\text { Variable } \\
\text { Cost } \\
\left(\mathrm{US} \$ \mathrm{ha}^{-1}\right)\end{array}$ & $\begin{array}{c}\text { Total Fixed } \\
\text { Cost } \\
(\text { US\$ ha } \\
\end{array}$ & $\begin{array}{l}\text { Total Cost } \\
\text { (US\$ ha }{ }^{-1} \text { ) }\end{array}$ & $\begin{array}{c}\text { Gross } \\
\text { Margin } \\
\left(\mathrm{US} \$ \mathrm{ha}^{-1}\right)\end{array}$ & $\begin{array}{l}\text { Net Return } \\
\left(\mathrm{US} \$ \mathrm{ha}^{-1}\right)\end{array}$ & $\begin{array}{l}\text { Benefit-Cost } \\
\text { Ratio (BCR) }\end{array}$ \\
\hline BARI SP-8 & $31.07 \pm 2.7$ & $4412 \pm 383$ & 1179 & 194 & 1373 & $3233 \pm 383$ & $3039 \pm 383$ & $3.21 \pm 0.28$ \\
\hline BARI SP-12 & $32.00 \pm 2.6$ & $4543 \pm 368$ & 1179 & 194 & 1373 & $3364 \pm 368$ & $3170 \pm 368$ & $3.31 \pm 0.27$ \\
\hline BARI SP-14 & $29.28 \pm 1.7$ & $4157 \pm 235$ & 1179 & 194 & 1373 & $2978 \pm 235$ & $2784 \pm 235$ & $3.03 \pm 0.17$ \\
\hline BARI SP-15 & $28.41 \pm 1.5$ & $4035 \pm 212$ & 1179 & 194 & 1373 & $2856 \pm 212$ & $2662 \pm 212$ & $2.94 \pm 0.15$ \\
\hline Local & $18.51 \pm 1.1$ & $2629 \pm 159$ & 1179 & 194 & 1373 & $1450 \pm 159$ & $1256 \pm 159$ & $1.91 \pm 0.12$ \\
\hline
\end{tabular}




\section{Discussion}

The tuberous root yield of sweet potato displays several positive associations with the plant and root characteristics [33]. The higher root yield of the tuberous roots is reliant on the higher tuberous root weight resulted in higher tuberous root diameter, more leaf number per plant, increase vine length, more tuberous root plant ${ }^{-1}$, increase the number of sweet potato vines plant ${ }^{-1}$, and a minimum influenced by increase tuberous root length [33]. Orange flesh sweet potato genotypes have high beta-carotene [8,29] in comparison with sweet potato cultivars having white, cream or yellow flesh. The color of the original flesh may also indicate the intensity of the pigment included. The more intense of the color of the root flesh, the higher the amount of beta-carotene [34]. The morphological and yield-contributing characters of sweet potatoes will be determined by the influence of the growing environment on the genetic makeup of the crop. These two factors will inter-relate throughout the plant's growing period so that the shape of the tuberous roots look like each other or dissimilar. If the impact of the growing condition is major, rather than the genetic impact, then there may be morphological distinctions of the varieties/cultivars [35]. These growing conditions/environments included climatic and soil conditions as well as water availability [36]. Some of the morphological characters such as leaf size, color, stem, petiole, skin and flesh color of sweet potato are stable and are not influenced by growing conditions, while morphological characters such as the length of vines and leaf stalk, leaf shape and yield of tuberous roots which can be easily changed as affected by the environment [37]. Our current findings on plant roots, root lengths, root diameters and root production agree with the findings [30,38-40].

In Bangladesh, due to high crop competition in the plain ecology and the use of local farming in the production system, the potential for sweet potato production is comparatively low, and the quantity and quality are also reduced. In our field trial, it was proved that the newly developed OFSP varieties produced higher root yield than the local cultivars, which indicates that the new varieties have good genetic characteristics to provide high yields in the various environments, and our statement agrees with [32]. Moreover, climatic conditions and intercultural operations according to cultivars/varieties also affect the productivity of sweet potatoes [41-43]. Root yield varies greatly between sweet potato varieties/cultivars and even individual plants of the same variety/cultivars, such as those affected by cultivation, breeding material, and growing environment and edaphic condition [44]. Genetic and environmental factors also affect on the morphological and physiological character, yield and dry matter production [45].

Therefore, it is very important to select suitable sweet potato varieties based on environmental conditions [41]. The overall yield performance of all studied varieties was comparatively low in Gaibandha than Rangpur location considering their potential yield. Stability analysis provides the level of productivity of a genotype to a certain environment [46]. BARI SP-14 had a relatively good yield maintaining stability in unfavorable locations and responding well to favorable locations followed by BARI SP-15. Further, the probable causes for its low yield were sandy to sandy loam soil having less moisture holding capacity, which may also be due to inadequate irrigation application at the time of root growth and development, inadequate intercultural management practices, and considered as neglected crops in the Char/riverbank areas.

Beta-carotene may vary from place to place and from year to year. This beta-carotene yield was initially controlled by the genetic factor. It is affected by the amount of irrigation during crop growth and the amount of fertilizer used for root production. But fertilizer application has a positive effect on beta-carotene content and generally agrees with the study [47-49] which revealed that increased potassium and zinc fertilization increased carotene levels in sweet potato roots. However, the amount of carotene increase fluctuates within the sweet potato genotype. Smolen and Sady [50] stated that nitrogen fertilization alone has no significant effects on the extent of carotenoid (in carrots). Thus, the difference between carotene components can be estimated by applying specific macro-components. Again, when the roots are stored in the soil until needed, the carotenoid and $\beta$-carotene 
content of the roots may be affected by the sweet potato variety and storage age of the roots [51,52].

The profit may be more or less due to the variation in the yield of sweet potato. The harmful aspects of sweet potato cultivation include lack of sweet potato vines (planting material) at farm level [53], awareness of sweet potato farmers about OFSP, storage capacity [54] and lack of processing facilities, lack of suitability, marketing structure and high marketing costs among producers [53-56]. The cost and returns analysis showed that labor cost was $33.58 \%$ followed by cost of acquisition of vines found $24.47 \%$ of the total cost of sweet potato cultivation and profitability of OFSP production.

The main problem faced by the sweet potato growers was the unavailability of quality vines. The second problem was indicated by farmers was the lack of storage facilities and lack of knowledge about storage techniques. Most farmers do not choose storage and so the roots were sold almost immediately in the local market and, as a result, people are mistreated by sweet potato farmers by marketing $[43,46]$.

The farmers also stated that they faced yield loss due to sweet potato weevil attacks. In addition to this, unpredicted weather due to uneven rainfall also influenced the sweet potato root yield. Numerous sweet potato growers also reported a shortage of labor at the time of planting and harvesting sweet potatoes.

These limits can be forwarded by on time and sufficient supply of planting materials (vines), generating awareness about OFSP varieties with improved cultivation systems and updating the market approach of sweet potatoes in Bangladesh resulting in the extended better ways for escalating farmers' income along with nutrition.

\section{Conclusions}

Growing OFSP in the riverbanks/Char areas of northern Bangladesh provides agronomic and economic benefits to producers. Farmers who find it difficult to grow rice, maize or wheat in the riverbanks/Char areas because of sandy and fallow land and shortage of water (especially for rice) may produce sweet potato as an alternative. Farmer's yield of OFSP in the riverbanks/Char area has an average of about $18.51 \mathrm{t} \mathrm{ha}^{-1}$ and entails a considerably reduced amount of irrigation and other inputs relative to other crops. However, among the cultivars, BARI SP-12 produced $73 \%$ more root yield ( $32 \mathrm{t} \mathrm{ha}^{-1}$ ) like BARI SP-8 by $68 \%$ higher yield ( $31.07 \mathrm{t} \mathrm{ha}^{-1}$ ) compared to the local cultivar over the locations. In terms of feasibility, BARI SP-12 performed the best and yielded $33.66 \mathrm{t} \mathrm{ha}^{-1}$ in Rangpur whereas BARI SP-8 performed the best in Gaibandha with an average yield of $31.89 \mathrm{tha}^{-1}$, which was 86 and $69 \%$ higher than that of the local cultivars. Conversely, the beta carotene (Vitamin-A precursor) was the greatest in BARI SP-14 (2957 kg ha ${ }^{-1}$ ) like BARI SP-15 (2952 $\mathrm{kg} \mathrm{ha}^{-1}$ ), whereas it was much lower in BARI SP-12 and BARI SP-8. In addition, BARI SP-8 and BARI SP-12 was found stable in specific locations and found economically profitable due to the highest root yield in the respective areas. Besides these two varieties, BARI SP-14 and BARI SP-15 were found stable in both locations. Finally, it may be concluded that BARI SP-8 and BARI SP-12 are suitable for cultivation in the Char areas of Gaibandha and Rangpur in terms of a good yield. Furthermore, BARI SP-14 and BARI SP-15 are found stable for both locations and can be cultivated in the Char areas. These four OFSP varieties can serve as a good source of beta-carotene (vitamin-A) among the Char dwellers' as well as the whole nation of Bangladesh.

Author Contributions: Conceptualization, A.-A.M., M.A.A., M.S.H.M.; methodology, A.-A.M., M.J.A. and M.N.A.; software, A.-A.M., M.J.A.; validation, A.-A.M., S.H., W.J.G. and E.H.M.S.R.; formal analysis, A.-A.M., M.J.A., M.N.A.; investigation, A.-A.M., M.J.A. and M.A.-A.H.T.; resources, A.-A.M.; data curation, A.-A.M., M.J.A. and A.H.; writing—original draft preparation, A.-A.M., W.J.G., S.H. and D.C.; writing—review and editing, S.H., W.J.G., M.M.A., M.A., A.G., M.A.A., A.H. and A.-A.M.; visualization, A.-A.M., A.H. and M.J.A.; supervision, A.-A.M.; project administration, A.-A.M., M.A., A.G. and D.C.; funding acquisition, A.-A.M., M.A., A.G., A.H. and D.C. All authors have read and agreed to the published version of the manuscript. 
Funding: The authors would like to thank the International Potato Center (CIP, Bangladesh) authority for awarding research expenses and also the Taif University Researchers Supporting Project number (TURSP 2020/257), Taif University, Taif, Saudi Arabia.

Institutional Review Board Statement: Not applicable.

Informed Consent Statement: Not applicable.

Data Availability Statement: Data may be available after request to the corresponding author.

Acknowledgments: We earnestly give thanks to the Director-General of Bangladesh Agricultural Research Institute (BARI) for delivering the services for this study and the authors extend their appreciation to Taif University Researchers Supporting Project number (TURSP 2020/257), Taif University, Taif, Saudi Arabia.

Conflicts of Interest: The author declares no conflict of interest.

\section{References}

1. Woolfe, J.A. Sweet Potato: An Untapped Food Resource; Cambridge University Press: Cambridge, UK, $1992 ;$ p. 643.

2. Bovell-Benjamin, A.C. Sweet potato: A review of its past, present, and future role in human nutrition. Adv. Food Nutr. Res. 2007, 52, 1-59.

3. Low, J.; Nyongesa, M.; Quinn, S.; Parker, M. (Eds.) Potato and Sweetpotato in Africa. Transforming the Value Chains for Food and Nutrition Security; CABI International: Boston, MA, USA, 2015; 632p, ISBN 978-1-78064-420-2. [CrossRef]

4. CIP (International Potato Centre). 2017. Available online: http://cipotato.org/research/sweetpotato-in-Africa (accessed on 11 August 2021).

5. FAO. The State of Food and Agriculture, Climate Change, Agriculture and Food Security; FAO: Rome, Italy, 2016; Available online: http:/ / www.fao.org/3/i6030e/i6030e.pdf (accessed on 14 August 2021).

6. Murugan, S.; Paramasivam, S.K.; Nedunchezhiyan, M. Sweet potato as animal feed and fodder. Fruit Vege. Cere. Sci. Biotech. 2012, 6, 106-114.

7. Chakrabarti, A.; Kumari, R.; Dey, A.; Bhatt, B.P. Sweet Potato-An Excellent Source of Livestock Feed. Krishi Sewa. 2014. Available online: http:/ / www.krishisewa.com/cms/articles/production-technology/391-sweet-potato.html (accessed on 13 August 2021).

8. Teow, C.C.; Truong, V.D.; McFeeters, R.F.; Thompson, R.L.; Pecota, K.V.; Yencho, G.C. Antioxidant activities, phenolic and beta-carotene contents of sweet potato genotypes with varying flesh colours. Food Chem. 2007, 103, 829-838. [CrossRef]

9. Antia, B.S.; Akpan, E.J.; Okon, P.A.; Umoren, I.U. Nutritive and anti-nutritive evaluation of sweet potatoes (Ipomoea batatas) leaves. Pakistan J. Nutr. 2006, 2, 166-168. [CrossRef]

10. Slafer, G.A.; Savin, R. Source-Sink relationships and grain mass at different positions within the spike in wheat. Field Crops Res. 1994, 37, 39-49. [CrossRef]

11. Mbwaga, Z.; Mataa, M.; Msabaha, M. Quality and yield stability of orange-fleshed sweet potato (Ipomoea batatas) varieties grown in different agro-ecologies. In Proceedings of the 8th African Crop Science Society Conference, Minya, Egypt, 27-31 October 2007; pp. 339-345.

12. Wilson, C.D.; Pace, R.D.; Bromfield, E.; Jones, G.; Lu, J.Y. Sweet potato in a vegetarian menu plan for NASA's Advanced Life Support Program. Life Support Biosph. Sci. 1998, 5, 347-351.

13. Wu, X.; Sun, C.J.; Yang, L.H.; Zeng, G.; Liu, Z.Y.; Li, Y.M. Beta-carotene content in sweet potato varieties from China and the effect of preparation on beta-carotene retention in the Yanshu. Innov. Food Sci. Emerg. Technol. 2008, 9, 581-586. [CrossRef]

14. Byers, T.; Perry, G. Dietary carotenes, vitamin C and vitamin E as protective antioxidants in human cancers. Ann. Rev. Nutr. 1992, 12, 139-159. [CrossRef] [PubMed]

15. Ahn, P.M. Tropical Soils and Fertilizer Use; Longman Scientific and Technical: Harlow, UK, 1993.

16. Tumwegamire, S.; Kapinga, R.; Zhang, D.; Crisnam, C.; Agilli, S. Opportunities for promoting orange-fleshed sweet potato among food based approach to combat vitamin A deficiency in sub-Saharan Africa. Afr. Crop Sci. J. 2004, 12, $241-253$.

17. Azad, A.K.; Miaruddin, M.; Oahab, M.A.; Sheikh, M.H.R.; Nag, B.L.; Rahman, M.H.H. Krishi Projukti Hatboi (Handbook on Agro-Technology), 9th ed.; Bangladesh Agricultural Research Institute: Gazipur, Bangladesh, 2020; pp. 35-37.

18. Hongyu, K.; García-Peña, M.; de Araújo, L.B.; Dias, C.T.S. Statistical analysis of yield trials by AMMI analysis of genotype $\times$ environment interaction. Biom. Lett. 2014, 51, 89-102. [CrossRef]

19. Kivuva, B.M.; Githiri, S.M.; Yencho, G.C.; Sibiya, J. Genotype $\times$ Environment interaction for storage root yield in sweet potato under managed drought stress conditions. J. Agril. Sci. 2014, 6, 41-56.

20. Adebola, P.O.; Shegro, A.; Laurie, S.M.; Zulu, L.N.; Pillay, M. Genotype $\times$ environment interaction and yield stability estimate of some sweet potato [Ipomoea batatas (L.) Lam] breeding lines in South Africa. J. Plant Breed. Crop Sci. 2013, 5, 182-186. [CrossRef]

21. Amare, B.; Abay, F.; Tsehaye, Y. Evaluation of sweet potato (Ipomea batatas L.) varieties for total storage root yield in south. Am. J. Trade Policy 2014, 1, 27-32. [CrossRef]

22. Purchase, J.L. Parametric Analysis to Describe Genotype $\times$ Environment Interaction and Yield Stability in Winter Wheat. Ph.D. Thesis, University of the Orange Free State, Bloemfontein, South Africa, 1997; pp. 19-22. 
23. Prakash, P.; Avinash, K.; Devesh, R.; Debdutt, B. Economic analysis of sweet potato farming and marketing in Odisha. J. Root Crops 2016, 42, 163-167.

24. Prakash, P.; Kishore, A.; Roy, D.; Behura, D.; Immanuel, S. Bio fortification for reducing hidden hunger: A value chain analysis of sweet potato in India. Agril. Econ. Res. Rev. 2017, 30, 20-30.

25. GAINS Project. Technological Empowerment and the Creation of Sustainable Livelihoods in Odisha State in India. 2013. Available online: http: / / www.orihort.in/Application/Download/Generating\%20Advances\%20in\%20Incmes\%20and\%20Nutrition \%20 through\%20Sweet\%20Potato\%20(GAIN).pdf (accessed on 8 September 2017).

26. Yildirim, Z.; Tokuşoğlu, Ö.; Öztürk, G. Determination of sweet potato [Ipomoea batatas (L.) Lam.] genotypes suitable to the Aegean region of Turkey. Turkish J. Field Crops 2011, 16, 48-53.

27. Alam, M.J.; Humphreys, E.; Sarkar, M.A.R.; Sudhir, Y. Intensification and diversification increase land and water productivity and profitability of rice-based cropping systems on the High Ganges River Floodplain of Bangladesh. Field Crops Res. 2017, 209, 10-26. [CrossRef]

28. Olivoto, T.; Lúcio, A.D.; Da Silva, J.A.; Marchioro, V.S.; de Souza, V.Q.; Jost, E. Mean performance and stability in multienvironment trials I: Combining features of AMMI and BLUP techniques. Agron. J. 2019, 111, 2949-2960. [CrossRef]

29. Rahman, M.H.; Patwary, M.M.A.; Barua, H.; Hossain, M.; Nahar, S. Evaluation of Orange Fleshed Sweet potato (Ipomoea batatas L.) Genotypes for Higher Yield and Quality. Agriculturists 2013, 11, 21-27. [CrossRef]

30. Rahaman, E.H.; Hossain, M.M.; Hoque, M.E.; Ali, M.R.; Mahmud, A.A.; Hasan, M.M.; Mohanta, H.C.; Bhuiyan, M.K.; Islam, M.S.; Hossain, M.J. Farmers preference and suitability assessment of BARI released Orange-Fleshed Sweet potato varieties in Charlands of Gaibandha. Bangladesh Hort 2015, 2, 1-11.

31. Shukla, G.K. Some statistical aspects of partitioning genotype environmental components of variability. Heredity 1972, 29, 237-245. [CrossRef]

32. Purchase, J.L.; Hatting, H.; Van Deventer, C.S. Genotype $\times$ environment interaction of winter wheat (Triticum aestivum L.) in South Africa: II. Stability analysis of yield performance. S. Afr. J. Plant Soil 2000, 17, 101-107. [CrossRef]

33. Reddy, R.; Soibam, H.; Ayam, V.S.; Panja, P.; Mitra, S. Morphological characterization of sweet potato cultivars during growth, development and harvesting. Indian J. Agric. Res. 2018, 52, 46-50. [CrossRef]

34. Saraswati, P.; Soplanit, A.; Syahputra, A.T.; Kossay, L.; Muid, N.; Ginting, E.; Lyons, G. Yield trial and sensory evaluation of sweet potato cultivars in Highland Papua and West Papua Indonesia. J. Trop. Agric. 2013, 51, 74-83.

35. Hughes, A.R.; Inouye, B.D.; Johnson, M.T.J.; Underwood, N.; Vellend, M. Ecological Consequences of Genetic Diversity. Ecol. Lett. 2008, 11, 609-623. [CrossRef] [PubMed]

36. Mwololo, J.K.; Mburu, M.W.K.; Muturi, P.W. Performance of sweet potato varieties across environments in Kenya. Int. J. Agric. Agri. Res. 2012, 2, 1-11.

37. Purbasari, K.; Sumadji, A.R. Studi variasi ubi jalar (Ipomoea batatas L.) berdasarkan karakter morfologi di Kabupaten Ngawi. Florea J. Biol. Pembelajarannya 2018, 5, 78-84. [CrossRef]

38. Jahan, M.A.; Siddique, M.A.R. Studies on Growth, Yield and Storage of Sweet Potato as Influenced by Variety and Time of Harvest. Master's Thesis, Department of Horticulture, Bangladesh Agricultural University, Mymensingh, Bangladesh, 2001; pp. $1-84$.

39. Rafique, F.; Fatema, K.; Rahman, M.H.; Hossain, M.M. Vegetative growth and yield performance of eight sweet potato genotypes. Bangladesh Hortic. 2015, 1-2, 103-110.

40. Hayati, M.; Zakaria, S.; Efendi; Anhar, A. Morphological characteristics and yields of several sweet potato (Ipomoea batatas L.) tubers. In Proceedings of the IOP Conference Series: Earth and Environmental Science 425 (2020) 012055, the 1st International Conference on Agriculture and Bioindustry, Banda Aceh, Indonesia, 24-26 October 2019. Available online: https:/ /iopscience. iop.org/article/10.1088/1755-1315/425/1/012055/pdf (accessed on 13 August 2021).

41. Mahmud, A.A.; Hassan, M.M.; Alam, M.J.; Molla, M.S.H.; Ali, M.A.; Mohanta, H.C.; Alam, M.S.; Islam, M.A.; Talukder, M.A.H.; Ferdous, M.Z.; et al. Farmers' Preference, Yield, and GGE-Biplot Analysis-Based Evaluation of Four Sweet potato (Ipomoea batatas L.) Varieties Grown in Multiple Environments. Sustainability 2021, 13, 3730. [CrossRef]

42. Antiaobong, E.E.; Bassey, E.E. Constraints and prospects of sweet potato (Ipomoea batatas (L.) Lam) production in humid environment of southeastern Nigeria. In Proceedings of the Second African Regional Conference on Sustainable Agriculture, Uyo, Nigeria, 4-7 November 2008; Governor's Office Annex: Uyo, Nigeria; pp. 68-72.

43. Antiaobong, E.E.; Bassey, E.E. Characterization and evaluation of six sweet potato varieties (Ipomoea batatas (L.) Lam) for quantitative and qualitative characters and tolerance to Cylas puncticollis, Boh in high humid environment of southeastern Nigeria. J. Agril. Res. Pol. 2009, 4, 17-21.

44. Ravi, V.; Saravanan, R. Crop Physiology of Sweet potato. Fruit, Vegetable and Cereal Science and Biotechnology. In Global Science Books; 6 (Special Issue I); Central Tuber Crops Research Institute: Thiruvananthapuram, India, 2012; pp. 17-29.

45. Ravi, V.; Indira, P. Crop Physiology of Sweet potato. Hortic. Rev. 1999, 23, 277-316.

46. Bernardo, R. Breeding for Quantitative Traits in Plants, 3rd ed.; University of Minnesota-Twin Cities, Stemma Press Woodbury: Woodbury, MN, USA, 2020.

47. Laurie, S.M.; Faber, M.; van Jaarsveld, P.J.; Laurie, R.N.; du Plooya, C.P.; Modisane, P.C. $\beta$-Carotene yield and productivity of orange-fleshed sweet potato (Ipomoea batatas L. Lam.) as influenced by irrigation and fertilizer application treatments. Sci. Hortic. 2012, 142, 180-184. [CrossRef] 
48. George, M.S.; Lu, G.; Zhou, W. Genotypic variation for potassium uptake and utilization efficiency in sweet potatoes. Field Crops Res. 2002, 77, 7-15. [CrossRef]

49. Abd El-Baky, M.M.H.; Ahmed, A.A.; El-Nemr, M.A.; Zaki, M.F. Effect of potassium fertilizer and foliar zinc application on yield and quality of sweet potato. Res. J. Agric. Biol. Sci. 2010, 6, 386-394.

50. Smoleń, S.; Sady, W. The effect of various nitrogen fertilization and foliar nutrition regimes on the concentrations of sugars, carotenoids and phenolic compounds in carrot (Daucus carota L.). Sci. Hortic. 2009, 120, 315-324. [CrossRef]

51. K'osambo, L.M.; Carey, E.E.; Misra, A.K.; Wilkes, J.; Hagenimana, V. Influence of age, farming site, and boiling on pro-vitamin A content in sweet potato (Ipomoea batatas (L.) Lam.) storage roots. J. Food Comp. Anal. 1998, 11, 305-321. [CrossRef]

52. Chattopadhyay, A.; Chakraborty, I.; Mukopadhayay, S.K.; Kumar, P.K.; Sen, H. Compositional changes of sweet potato as influenced by cultivar, harvest date and cooking. Acta Hortic. 2006, 703, 211-218. [CrossRef]

53. Ahmed, M.R. Yield Performance of Sweet Potato Cultivation at Farmers' Field. Master's Thesis, Department of Agricultural Extension and Information System, Sher-e-Bangla Agricultural University, Dhaka, Bangladesh, 2018; p. 64.

54. Abrham, T.; Beshir, H.M.; Haile, A. Sweet potato production practices, constraints, and variety evaluation under different storage types. Food Energy Secur. 2020, 10, e263.

55. Sugri, I.; Maalekuu, B.K.; Gaveh, E.; Kusi, F. Sweet potato Value Chain Analysis Reveals Opportunities for Increased Income and Food Security in Northern Ghana. Adv. Agri. 2017, 2017, 1-14. [CrossRef]

56. Ezin, V.; Quenum, F.; Bodjrenou, R.H.; Kpanougo, C.M.I.; Kochoni, E.M.G.; Chabi, B.I.; Ahanchede, A. Assessment of production and marketing constraints and value chain of sweet potato in the municipalities of Dangbo and Bonou. Agric. Food Secur. 2018, 7, 15. [CrossRef] 